Short Communication

\title{
DNA barcoding of Brazilian sea turtles (Testudines)
}

\author{
Sarah M. Vargas, Flávia C.F. Araújo and Fabrício R. Santos \\ Laboratório de Biodiversidade e Evolução Molecular, Instituto de Ciências Biológicas, \\ Universidade Federal de Minas Gerais, Belo Horizonte, MG, Brazil.
}

\begin{abstract}
Five out of the seven recognized species of sea turtles (Testudines) occur on the Brazilian coast. The Barcode Initiative is an effort to undertake a molecular inventory of Earth biodiversity. Cytochrome Oxidase c subunit I (COI) molecular tags for sea turtle species have not yet been described. In this study, COI sequences for the five species of sea turtles that occur in Brazil were generated. These presented widely divergent haplotypes. All observed values were on the same range as those already described for other animal groups: the overall mean distance was $8.2 \%$, the mean distance between families (Dermochelyidae and Cheloniidae) $11.7 \%$, the mean intraspecific divergence $0.34 \%$, and the mean distance within Cheloniidae $6.4 \%$, this being 19 -fold higher than the mean divergence observed within species. We obtained species-specific COI barcode tags that can be used for identifying each of the marine turtle species studied.
\end{abstract}

Key words: barcodes, sea turtles, Cytochrome Oxidase c subunit I (COI).

Received: July 17, 2008; Accepted: December 18, 2008.

Marine turtles (Chelonioidea) are divided into two families, the mono-specific Dermochelyidae containing the leatherback turtle Dermochelys coriacea, and the Cheloniidae, with six recognized species divided into two tribes, Chelonini and Carettini. Chelonini is represented by the closely related green turtle Chelonia mydas and flatback turtle Natator depressus. Carettini includes the loggerhead turtle Caretta caretta, the olive and Kemp's ridley turtles, Lepidochelys olivacea and L. kempi, respectively, and the hawksbill turtle Eretmochelys imbricata (Ekert et al., 1999; Plotkin, 2007).

The "Barcode of Life" Consortium is a worldwide initiative devoted to undertaking a molecular inventory of Earth biodiversity. After having been demonstrated that the Cytochrome Oxidase $c$ subunit I (COI) gene of the mitochondrial DNA (mtDNA) could be successfully used for identifying North American bird species (Hebert et al., 2004), many other vertebrate COI bar-codes have been produced (Vilaça et al., 2006; Clare et al., 2007; Chaves et al., 2008).

Five out of the seven recognized marine turtle species occur on the Brazilian coast, namely the loggerhead (Caretta caretta), the hawksbill (Eretmochelys imbricata), the green (Chelonia mydas), the olive ridley (Lepidochelys olivacea) and the leatherback (Dermochelys coriacea) (Marcovaldi and Marcovaldi, 1999).

Send correspondence to Sarah M. Vargas. Departamento de Biologia Geral, Instituto de Ciências Biológicas, Universidade Federal de Minas Gerais, Caixa Postal 486, 30161-970 Belo Horizonte, MG, Brazil. E-mail: sarahmvbio@yahoo.com.br.
The large-scale sequencing of a single or few genes in taxonomic studies, denominated the Barcode initiative, aims at representing a practical method for species identification, as well as for providing insights into the evolutionary diversification of life (Stoeckle, 2003). Besides its usefulness in taxonomy, the barcode methodology is expected to be of great utility in conservation biology, for example, when performing biodiversity surveys. It could also be applied when traditional methods are inefficacious, as in the identification of eggs and larval forms, and in the analysis of stomach contents or excreta to determine food webs (Stoeckle, 2003). Furthermore, it can be potentially employed in forensic cases to identify the source of tissue samples obtained from the illegal commerce or use of eggs and meat.

Besides being eaten as food, in various human cultures the eggs of all turtle species are believed to possess aphrodisiac attributes. Turtle-egg consumption is believed to be the main cause for the severe decline in many sea turtle populations (Thorbjarnarson et al., 2000). The use of turtle meat as food is also worthy of mention, especially in the case of green turtles which are widely hunted in such places as Costa Rica, Mexico, Venezuela, Australia and Papua New Guinea (Lefever, 1992; Kowarsky, 1995; Nabhan et al., 1999). Thus, barcode methodology could be applied wherever turtle meat and eggs are eaten or trafficked, as a way of identifying species-source. In this way, barcode surveys could be used in sea turtle conservation and for alerting both the population and conservationists as to the local level of species-threat. 
DNA barcodes could also be applied in field research for the identification of lost nests and turtles stranded on beaches and frequently encountered in an advanced state of decomposition, thereby complicating correct species identification. Another possibility is the rapid identification of interspecific hybrids, which can be as frequent as $45 \%$ in the population of E.imbricata of Bahia, Brazil (Lara-Ruiz et al., 2006).

In this work, we generated COI barcodes and evaluated their usefulness for discriminating the five species of sea turtles occurring in Brazil.

Twenty six turtles from five species (Lepidochelys olivacea $\mathrm{n}=3$, Chelonia mydas $\mathrm{n}=3$, Caretta caretta $\mathrm{n}=4$, Eretmochelys imbricata $\mathrm{n}=8$ and Dermochelys coriacea $\mathrm{n}=8$ ) were sampled from beaches in different states of Brazil (Table 1). Several of the individuals had been used in prior studies on control-region sequences, namely from $E$. imbricata $(\mathrm{n}=119)($ Lara-Ruiz et al., 2006), D. coriacea $(\mathrm{n}=63)($ Vargas et al., 2008) and C. caretta $(\mathrm{n}=84)($ Reis et al., unpublished), which thus favored our selection of the most divergent individuals within each species for the present analysis.

Fresh skin biopsies were taken from the front flipper of live animals and stored at room temperature in ethanol $70 \%$, until total DNA was extracted as previously described (Lara-Ruiz et al., 2006). For L. olivacea, the COI mitochondrial gene was amplified as a whole by using the specific primer SOCOF1 developed in our laboratory, as well as the H8121 primer designed by M. D. Sorenson (see Internet Resources). LCO1490 and HCO2198 primers developed by Folmer et al. (1994) were used for the remaining four species. PCR reaction mixes of $15 \mu \mathrm{L}$ included $2 \mu \mathrm{L}$ of genomic DNA ( $40 \mathrm{ng}), 1 \mathrm{U}$ of Taq polymerase (Phoneutria $^{\circledR}$ ), $200 \mu \mathrm{M}$ of dNTPs, $1 \mathrm{X}$ Tris-KCl buffer with $1.5 \mathrm{mM} \mathrm{MgCl}_{2}\left(\right.$ Phoneutria $\left.^{\circledR}\right)$ and $0.5 \mu \mathrm{M}$ of each primer. Before sequencing, the PCR products were cleaned by precipitation, using $20 \%$ polyethyleneglycol (Lara-Ruiz et al., 2006). Sequencing reactions were carried out with each

Table 1 - Sampling sites in Brazil and control region haplotypes.

\begin{tabular}{|c|c|c|c|}
\hline Specie & ID & Location & Control region haplotype \\
\hline C. caretta & R0269 & Elevação do Rio Grande (Rio Grande do Sul) & A33* \\
\hline C. caretta & R0273 & Elevação do Rio Grande (Rio Grande do Sul) & A34* \\
\hline C. caretta & R0370 & Elevação do Rio Grande (Rio Grande do Sul) & $\mathrm{A} 2 *$ \\
\hline C. caretta & R0275 & Elevação do Rio Grande (Rio Grande do Sul) & A11* \\
\hline L. olivacea & R0446 & Praia Tigre da Base (Sergipe) & - \\
\hline L. olivacea & R0448 & Praia Ponta dos Mangues (Sergipe) & - \\
\hline L. olivacea & R0447 & Praia Tigre da Base (Sergipe) & - \\
\hline C. mydas & R0450 & Fernando de Noronha (Pernambuco) & - \\
\hline C. mydas & R0449 & Fernando de Noronha (Pernambuco) & - \\
\hline C. mydas & R0449 & Fernando de Noronha (Pernambuco) & - \\
\hline E. imbricata & R0051 & Praia do Forte (Bahia) & EiBR10** \\
\hline E. imbricata & R0035 & Atol das Rocas (Rio Grande do Norte) & EiBR12*** \\
\hline E. imbricata & R0102 & Fernando de Noronha (Pernambuco) & EiBR16** \\
\hline E. imbricata & R0062 & Praia do Forte (Bahia) & EiBR9** \\
\hline E. imbricata & R0104 & Fernando de Noronha (Pernambuco) & EiBR14*** \\
\hline E. imbricata & R0068 & Atol das Rocas (Rio Grande do Norte) & EiBR5*** \\
\hline E. imbricata & R0029 & Atol das Rocas (Rio Grande do Norte) & EiBR6*** \\
\hline E. imbricata & R0071 & Atol das Rocas (Rio Grande do Norte) & EiBR7*** \\
\hline D. coriacea & R0418 & Elevação do Rio Grande (Rio Grande do Sul) & Dc_A2**** \\
\hline D. coriacea & R0424 & Elevação do Rio Grande (Rio Grande do Sul) & Dc_I**** \\
\hline D. coriacea & R0410 & Elevação do Rio Grande (Rio Grande do Sul) & Dc_A3**** \\
\hline D. coriacea & R0430 & Elevação do Rio Grande (Rio Grande do Sul) & Dc_C C**** \\
\hline D. coriacea & R0392 & Elevação do Rio Grande (Rio Grande do Sul) & Dc_A1**** \\
\hline D. coriacea & R0402 & Elevação do Rio Grande (Rio Grande do Sul) & Dc_A1**** \\
\hline D. coriacea & R0414 & Elevação do Rio Grande (Rio Grande do Sul) & Dc_C**** \\
\hline D. coriacea & R0437 & Elevação do Rio Grande (Rio Grande do Sul) & Dc_A4**** \\
\hline
\end{tabular}

*Reis et al., unpublished. **Lara-Ruiz et al., 2006. ***Lara-Ruiz et al., unpublished. ****Vargas et al., 2008. 
primer in a final volume of $10 \mu \mathrm{L}$ containing $2 \mu \mathrm{L}$ of purified PCR product, $3 \mu \mathrm{L}$ of ultrapure water, $1 \mu \mathrm{L}$ of primer $(5 \mu \mathrm{M})$ and $4 \mu \mathrm{L}$ of sequencing kit (ET DYE Terminator Kit, Amersham Biosciences). Sequencing products were precipitated with ammonium acetate and ethanol, dried at room temperature, dissolved with formamide-EDTA and run in a MegaBACE 1000 automatic sequencer (General Electric Healthcare).

Consensus sequences (\# BBT001-08 to BBT026-08 are available in the BOLD database - see Internet Resources) were obtained and checked with the software Phred v. 0.20425 (Ewing et al., 1998), Phrap v. 0.990319 and Consed 12.0 (Gordon et al., 1998, see Internet Resources). Alignments were performed using Clustal X (Thompson et al., 1997), with a manual edition, whenever necessary. Sequence divergence among different haplotypes was estimated with MEGA 3.0 software (Kumar et al., 2004) by using the Kimura 2-parameter (K2p) distance model (Nei and Kumar, 2000). MEGA 3.0 was also used to construct a Neighbor-Joining (NJ) tree based on the K2p model with 10,000 bootstrap replicates.

A $589 \mathrm{bp}$ COI fragment was analyzed in this study. The sequences obtained were aligned and compared with another GenBank COI sequence for Chelonia mydas (\#AB012104). These comparisons revealed neither stop nor nonsense codons, neither were alignment gaps found. Although specimens of $D$. coriacea bearing six different control region haplotypes were analyzed, only one COI haplotype was encountered in this species. Different COI haplotypes were found for E. imbricata (four haplotypes) and $C$. caretta (three haplotypes), the average intra-specific K2P distances being $0.9 \%$ and $0.8 \%$, respectively (Table $2)$, thereby exceeding values encountered in other studies, such as $0.6 \%$ for neotropical bats (Clare et al., 2007) and $0.34 \%$ for Brazilian birds (Vilaça et al., 2006). Nucleotide divergence among species was high, ranging from $6.3 \%$ for L. olivacea and C. caretta to $13.9 \%$ for C. mydas and D. coriacea (Table 2).

The overall mean distance was $8.2 \%$ and the mean distance between the families Dermochelyidae and Cheloniidae, $11.7 \%$. The mean distance within Cheloniidae
Table 2 - Mean sequence divergence (K2P) within species (underlined number) and between pairs of sea turtle species found in Brazil.

\begin{tabular}{lccccc}
\hline & $C m$ & $C c$ & $L o$ & $E i$ & $D c$ \\
\hline Chelonia mydas (Cm) & $\underline{0.000}$ & & & & \\
Caretta caretta (Cc) & 0.096 & $\underline{0.008}$ & & & \\
Lepidochelys olivacea (Lo) & 0.084 & 0.063 & $\underline{0.000}$ & & \\
Eretmochelys imbricata (Ei) & 0.086 & 0.089 & 0.079 & $\underline{0.009}$ & \\
Dermochelys coriacea (Dc) & 0.139 & 0.122 & 0.124 & 0.103 & $\underline{0.000}$ \\
\hline
\end{tabular}

was $6.4 \%, 19$ times higher than the mean divergence observed within species $(0.34 \%)$. Only one haplotype was discriminated in Dermochelyidae, therefore the mean distance was zero. The COI gene sequences significantly discriminated all the species ( $99 \%$ bootstrap support), but did not split the two Cheloniidae tribes (Carettini and Chelonini), as can be seen in the NJ tree (Figure 1).

The autapomorphic sites discovered in each species are shown in Table 3. Most of the 71 autapomorphic sites were found in $D$. coriacea (32 sites), as expected, since Dermochelyidae diverged from the Cheloniidae in the late Cretaceous about 100 million years ago (Spotila, 2004). E. imbricata presented six autapomorphic sites, L. olivacea eight, $C$. mydas eighteen and C. caretta seven.

These autapomorphic characters, which are supposedly intraspecific synapomorphies, should be considered with caution since they were found in only a few individuals from each species, although we had pre-selected highly divergent mtDNA sequences. Some of these characters may thus not appear as synapomorphic in a broader sampling study.

The finding of characteristic species-specific COI sequences offers the prospect of identifying marine turtle species by using DNA barcode methodology as an auxiliary tool for taxonomy. This can also be used during field work, when identifying lost nests, animals stranded on beaches or those killed as part of the bycatch in fishery nets. A further use is in forensic litigation when turtle eggs or meat are the only available material.

Table 3 - Autapomorphic characters (highlighted in black) found in all individuals within each sea turtle species.

\begin{tabular}{|c|c|}
\hline Species & COI variable sites \\
\hline & 00000111111111111222222223333333333333444444444445555555555555555 \\
\hline & 02568012345677889144558990011334566789000134446890011123344567888 \\
\hline & 95401213910257698039895176926038409270258421478725867981703249258 \\
\hline Dermochelys coriacea $(\mathrm{n}=8)$ & ACGCTCCCGTCCCTAAGACGTCTACCTTCACTCTTGTAATTCCTATATTTTATGATACCTCTTTT \\
\hline Chelonia mydas $(\mathrm{n}=3)$ & 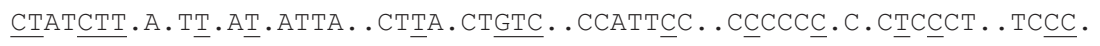 \\
\hline Caretta caretta $(\mathrm{n}=4)$ & 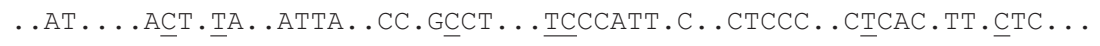 \\
\hline Lepidochelys olivacea $(\mathrm{n}=3)$ & ..АT....А. \\
\hline Eretmochelys imbricata $(\mathrm{n}=8)$ & 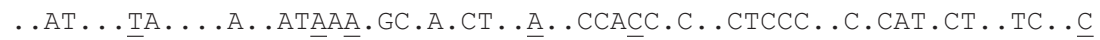 \\
\hline
\end{tabular}




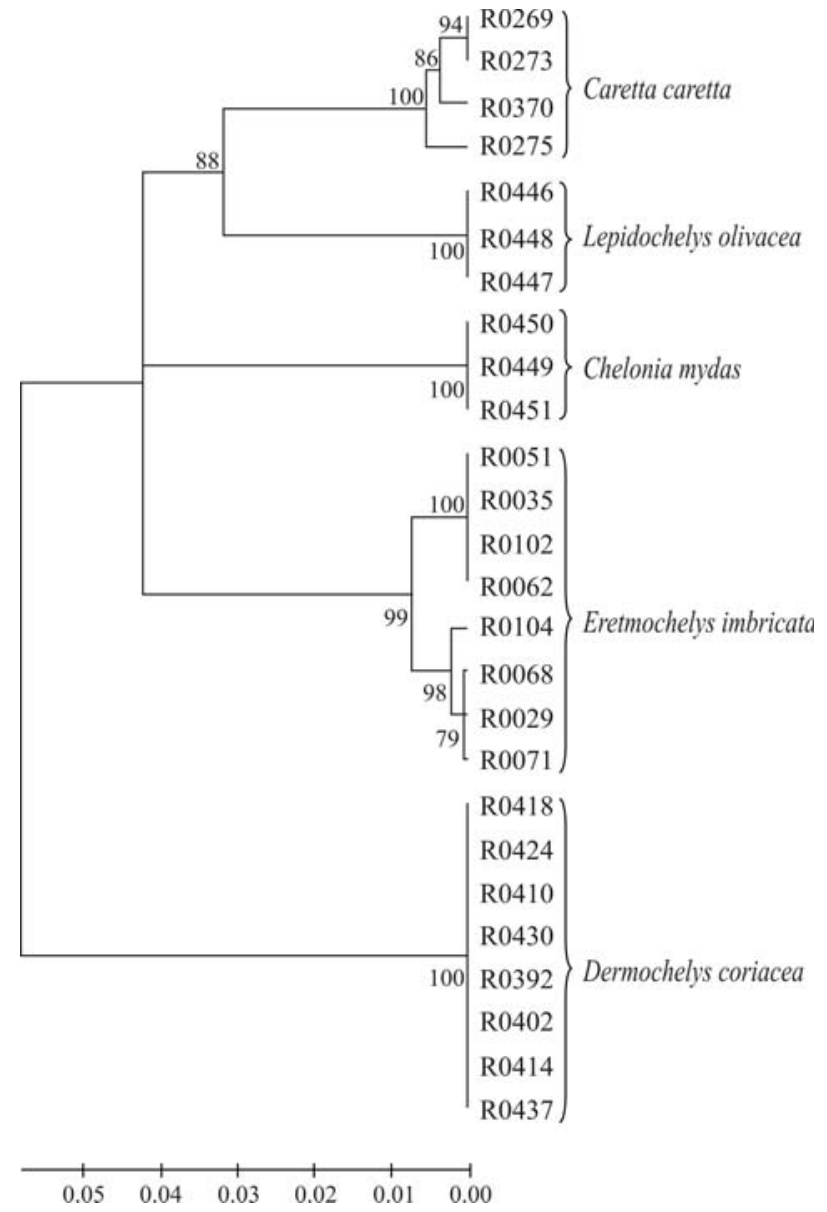

Figure 1 - Neighbor-Joining tree of 589 COI sequences for five sea turtle species. Bootstrap support values are indicated on the branches. Three haplotypes were discriminated for C. caretta $(\mathrm{n}=4)$, one for Lepidochelys olivacea $(\mathrm{n}=3)$, one for Chelonia mydas $(\mathrm{n}=3)$, four for Eretmochelys imbricata $(\mathrm{n}=8)$ and one for Dermochelys coriacea $(\mathrm{n}=8)$.

Despite these advantages, DNA barcoding must be employed with care in those sites where hybridization has already been registered, as in the hawksbill population of Bahia (Brazil), where 50 out of 119 individuals manifested two of the haplotypes characteristic of the loggerhead species (Lara-Ruiz et al., 2006). Hybrid turtles display mitochondrial DNA characteristics of the maternal species against a background of the maternal and paternal nuclear genes from both species, thus composing a mosaic that may lead to incorrect taxonomic identification. Nevertheless, in most cases COI barcodes can be used for the trustworthy identification of maternal ancestry and testing the possibility of hybridization when discrepancies between morphology and expected mtDNA inheritance are encountered.

\section{Acknowledgments}

SMV received supported from FAPEMIG and CAPES (Brazil), and FCFA and FRS from CNPq (Brazil). Field work was sponsored by PETROBRAS/CENPES (Brazil), and lab work funded by CNPq, FAPEMIG and
CAPES (Brazil). We wish to thank Marta Svartman for the technical review of the text, and Danielle S. Monteiro and Sergio Estima from NEMA (Brazil) and Luciano Soares from the Fundação Pró-Tamar (Brazil) for providing samples and information concerning field work.

\section{References}

Clare EL, Lim BK, Engstrom MD, Eger JL and Hebert PD (2007) DNA barcoding of Neotropical bats: Species identification and discovery within Guyana. Mol Ecol Notes 7:184-190.

Chaves AV, Clozato CL, Lacerda DR, Sari EHR and Santos FR (2008) Molecular taxonomy of Brazilian tyrant-flycatchers (Passeriformes, Tyrannidae). Mol Ecol Resour 8:11691177.

Ekert KL, Bjorndal KA, Abreu-Grobois FA and Donnelly M (1999) Research and Management Techniques for the Conservation of Sea Turtles. IUCN/SSC Marine Turtle Specialist Group, Gland, 235 pp.

Ewing B, Hillier L, Wendi M and Green P (1998) Basecalling of automated sequencer traces using Phred I: Accuracy assessment. Genome Res 8:175-185.

Folmer OM, Black W, Hoeh R, Lutz R and Vrijenhoek R (1994) DNA primers for amplification of mitochondrial cytochrome c oxidase subunit I from diverse metazoan invertebrates. Mol Mar Biol Biotechnol 3:294-299.

Gordon D, Abajian C and Green P (1998) Consed: A graphical tool for sequence finishing. Genome Res 8:195-202.

Hebert PDN, Stoeckle MY, Zemlak TS and Francis CM (2004) Identification of birds through DNA barcodes. PLoS Comput Biol 2:1657-1663.

Kowarsky J (1995) Subsistence hunting of turtle in Australia. In: Bjorndal KA (ed) Biology and Conservation of Sea Turtle Revised Edition. Smithsonian Institution Press, Washington, pp 305-313.

Kumar S, Tamura K and Nei M (2004) MEGA3: Integrated software for Molecular Evolutionary Genetics Analysis and sequence alignment. Brief Bioinform 5:150-163.

Lara-Ruiz P, Lopez GG, Santos FR and Soares LS (2006) Extensive hybridization in hawksbill turtles (Eretmochelys imbricata) nesting in Brazil revealed by mtDNA analyses. Conserv Genet 7:773-781.

Lefever H (1992) Turtle Bongue: Afro-Caribbean Life and Culture in a Costa Rican Village. Susquehanna University Press, Selinsgrove, 249 pp.

Marcovaldi MA and Marcovaldi GG (1999) Marine turtles of Brazil: The history and structure of Projeto TAMAR-IBAMA. Biol Cons 91:35-41.

Nabhan G, Govan H, Eckert SA and Seminoff JA (1999) Sea Turtle workshop for the indigenous Ser tribe. Marine Turtle Newsletter 86:44.

Nei M and Kumar S (2000) Molecular Evolution and Phylogenetics. Oxford University Press, New York, 333 pp.

Plotkin PT (2007) Biology and Conservation of Ridley Sea Turtles. JHU Press, Baltimore, $356 \mathrm{pp}$.

Spotila JR (2004) Sea Turtles: A Complete Guide to Their Biology, Behavior, and Conservation. JHU Press, Baltimore, $227 \mathrm{pp}$.

Stoeckle M (2003) Taxonomy, DNA, and the Bar Code of Life. Bioscience 53:796-797. 
Thompson JD, Gibson TJ, Plewniak F, Jeanmougin F and Higgins DG (1997) The Clustal X windows interface: Flexible strategies for multiple sequence alignment aided by quality analysis tools. Nucleic Acids Res 24:4876-4882.

Thorbjarnarson JB, Lagueux CJ, Bolze D, Klemens MW and Meylan AB (2000) Human use of turtles: A worldwide perspective. In: Klemens MW (ed) Turtle Conservation. Smithsonian Institution Press, Washington and London, pp 33-84.

Vargas SM, Araújo FCF, Monteiro DS, Almeida AP, Soares LS and Santos FR (2008) Genetic diversity and origin of Leatherback turtles (Dermochelys coriacea) from the Brazilian coast. J Hered 99:215-220.

Vilaça ST, Lacerda DR, Sari HER and Santos FR (2006) DNAbased identification to Thamnophilidae (Passeriformes) species: The first barcodes of Neotropical birds. Rev Bras Ornitol 14:7-13.

\section{Internet Resources}

Avian mtDNA primers: http://people.bu.edu/msoren/Bird. mt.Primers.pdf (February 9, 2008).

Barcode of Life Data System: http://www.boldsystems.org (June 27, 2008)

Consortium of the Barcode of life: http://www.barcoding.si.edu (May 14, 2008).

Phrap and Consed software: http://www.phrap.org (April 2, 2008).

Projeto Tamar: http://www.tamar.org.br (May 14, 2008).

Associate Editor: João S. Morgante

License information: This is an open-access article distributed under the terms of the Creative Commons Attribution License, which permits unrestricted use, distribution, and reproduction in any medium, provided the original work is properly cited. 